\title{
Acknowledgments
}

The impetus for this book goes back to discussions with friends starting around 2000, as I began to sense new developments in Latin American countries and as I taught an introductory course on the region at Temple University. In 2008, I began writing drafts and interviewing people in various countries. Among those who were helpful with ideas, encouragement, hosting me, or other forms of assistance were Eduard Barrebes, Edgar Bermúdez, Joe Broderick, Aurora Camacho de Schmidt, Mark Castro, Jesús Abad Colorado, Guillermo Corado and Isabel de Corado, Héctor Endara, Dick Erstad, Phil Evanson, Karen Faulkner, Dave Farrel, Jean FriedmanRudovsky, Noah Friedman-Rudovsky, Martín Gárate, Ana María Gómez, Mary Day Kent, Dan Levine, Milton Machuca, Elsie Monge, David Murray, Gene Palumbo, Valeria Rezende, Amanda Romero, Art Schmidt, Oscar Tabares, Leandro Vetcher, Joe Walsh, Ron Webb, and María Zúñiga. Reading the manuscript or portions of it and offering helpful comments were John Chasteen, Tony Equale, June Erlick, Phil Evanson, Ann Farnsworth-Alvear, Ann Helwege, Manuel Lombera, Josh Markel, Art Schmidt, and Tom Quigley. I wish to thank Noah Friedman-Rudovsky, Tommie Sue Montgomery, Edgar Romero, and Julián García for their fine photographs, and Sigfus Breidfford for preparing the graphs and maps. None of those named are responsible for errors and shortcomings.

I would like to thank Theresa May of the University of Texas Press for her enthusiastic acceptance of the proposal and manuscript; the anonymous readers for their criticisms; Kerry Webb, Angelica Lopez, Lynne Chapman, and other staff at the Press for bringing it to completion; and Nancy Warrington for her thorough copyediting. As always, I am in debt to my wife, Angela Berryman, who has been my partner in involvement with Latin America for several decades. 
THIS PAGE INTENTIONALLY LEFT BLANK 


\section{Latin America at 200}


